症例

胃原発小細胞癌と腎細胞癌の同時性重複癌の 1 例

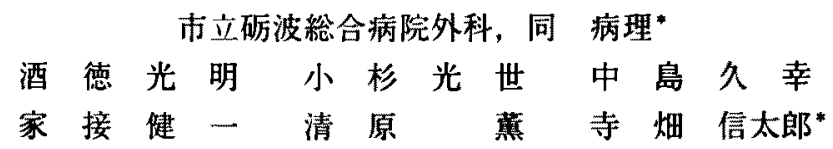

症例はめまいと嘔吐を主訴に来院した 66 歳男性. 上部消化管内梘镜検查で胃前庭部小 等に中心陥凹を有する隆起性病変を認め，生検で小細胞癌疑いであった．腹部 CT, MRI 検查で左腎上極に $2.5 \mathrm{~cm}$ の腫瘤と右腎低形成を認めた。胃切除術と左腎部分切除術を施

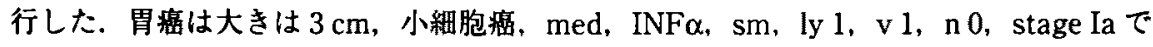
あった腎細胞癌は $2.5 \mathrm{~cm}$ で, papillary type, granular cell subtype であり，一部で被膜に

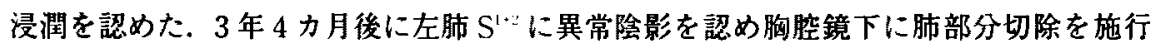
した。腎細胞㿋の転移であり，術後インターフェロン治療を行った。初回手術から 5 年 以上経過したが胃小細胞癌の再発徴候なく，また術後腎機能低下による生活の質の低下 なく生存中である，胃原発小細胞癌の予後はきわめて不良とされているが，自験例は長 期生存し，かつ腎細胞癌が重複したきわめて稀な 1 例と考え報告した。

索引用語：同時性重複癌，胃小細胞瘦，腎細胞癌

緒言

胃原発の小細胞瘦は稀な疾患であり，その予後はき わめて不良であるとされている.このたび, 5 年以上長 期生存中の胃原発小細胞癌と腎細胞癌との同時性重複 癌の 1 例を経験したので報告する。

\section{症例}

症例 : 66 歳, 男性.

主訴：めまいと湢吐。

家族歴：特記事項なし。

既往歴：1988 年から脳梗塞にて内科通院中である.

現病歴：1993 年 12 月めまいと嘔吐を認め, 当院を 受診した. 脳梗塞再発を疑い, 頭部 CT, MRI 検查を施 行するも異常なく，腹部精查目的に上部消化管内視鏡 検查を施行した.

入院時現症：体格中等，栄養良. 貣血，黄㾝なく， 頚部、胸部に異常なし、腹部は平坦で軟，腫疽を触知 しなかった.

入院時検查所見：血液一般，生化学的検查に異常を 認めなかった。腫瘍マーカーはCEA $1.6 \mathrm{ng} / \mathrm{ml}, \mathrm{CA}$ 19-9 $12.5 \mathrm{U} / \mathrm{ml}$, AFP $2.6 \mathrm{ng} / \mathrm{ml}$, NSE $6.1 \mathrm{ng} / \mathrm{ml}$. $\mathrm{SCC} 1.4 \mathrm{ng} / \mathrm{ml}$ と正常範囲内であった。 セロトニン

1999 年 4 月 6 日受付 1999 年 7 月 21 日採用
$10.0 \mathrm{mcg} / \mathrm{dl}$, 尿中 5 HIAA $6.2 \mathrm{mg} / \mathrm{l}$ と正常範囲内で あった。

上部消化管内視鏡検查：胃前庭部小率に中央に中心 宿凹を有する隆起性病変を認めた。隆起の立ち上がり が急峻な粘膜下腫膓样で, 表面粘膜は正常粘膜が引き 延ばされた様を呈した，中心陥凹は深く周辺にはわず かに再生上皮を認めたが、明らかな福腫を疑う所見は なかった（图 1).中心宿凹周辺から4個生検したとこ ろ 1 個に group $\mathrm{V}$ ，小細胞癌疑いの所見が得られた。

胸部レントゲン, CT 検查 : 肺小細胞㿋の胃転移を 疑い，胸部レントゲン検査. CT 検査を施行したが異常 はなかった。

腹部 CT, MRI 検查：肝転移、リンパ節腫大は認めな いが、右腎の低形成と左腎上極に $2.5 \mathrm{~cm}$ 大の被膜を有 する腫韵を認めた(図 2)。

堅機能検查：DMSA 腎スキャン、DTPA 腎レノグ ラムで右腎機能は認めなかった。

手術所見：1994年 1 月 18 日進行胃癌と左腎細胞癌 の診断で手術を施行した．上腹部正中切開にて開腹し た. 肝、腹膜転移なく、明らかなリンパ節転移もなかっ た．胃癌は槳膜に露出はなかったが，胃前庭部小彎に 腫瘦として触知した．D3リンパ節廊清を伴う胃切除 術を施行した。摘出標本は幽門輪から $3 \mathrm{~cm} に 3 \times 2 \mathrm{~cm}$ 

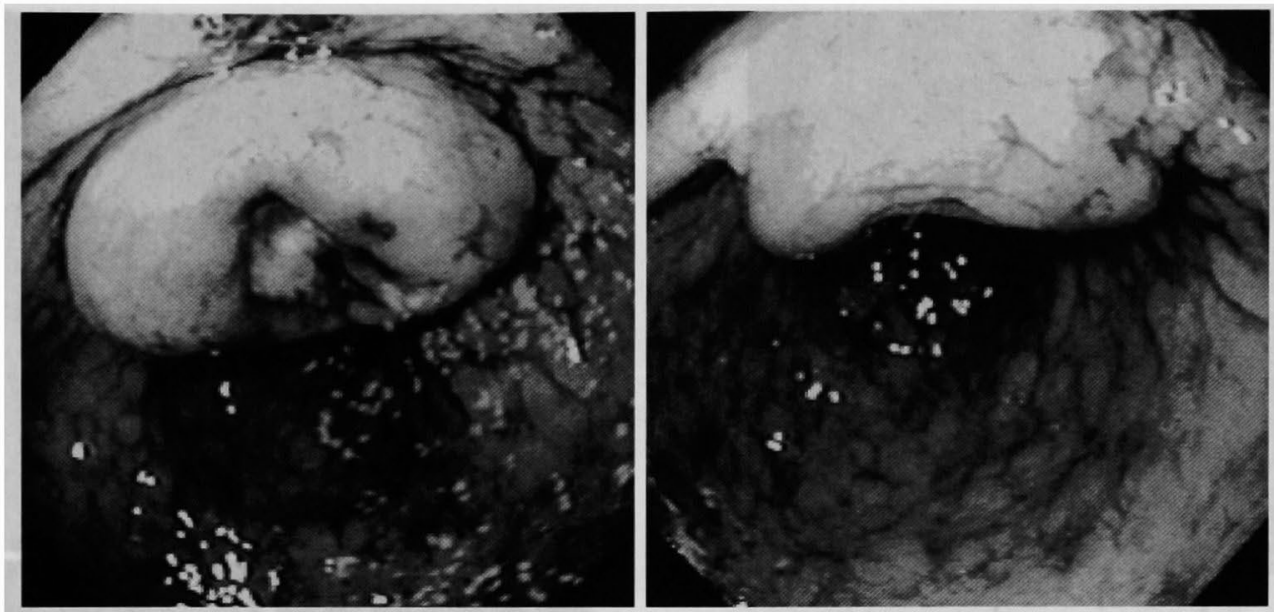

図 1 上部消化管内視鏡所見：胃前庭小攀に中心陥凹を有する隆起性病変を認めた。 隆起の立ち上がりの急峻な粘膜下腫瘍所見を示した。

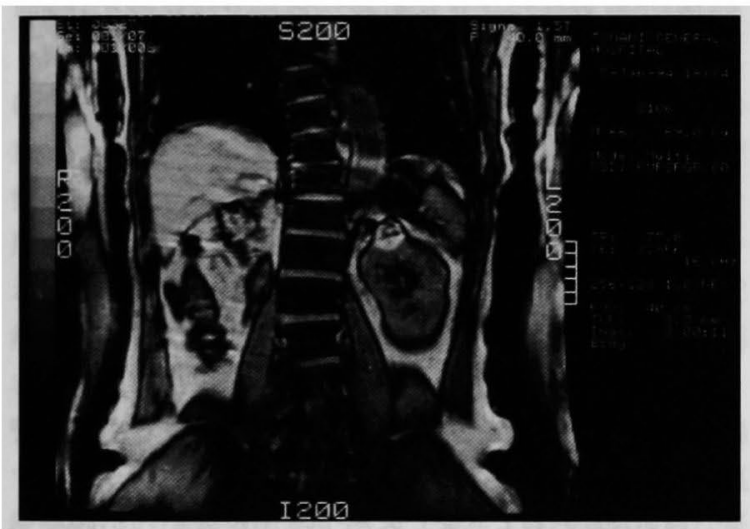

図 2 腹部 MRI 所見：右腎の低形成と左腎上極に 2.5 $\mathrm{cm}$ 大の腫瘍を認めた（造影 T l 強調冠状断像）.

の 2 型様腫瘍を認めた (図 3 ). 左腎細胞癌は $3 \mathrm{~cm}$ 未満 で，明らかな被膜浸潤や肉眼的にリンパ節転移なく堅 部分切除術を施行した（図 4 ).

病理組学的所見：胃の腫瑝は紐胞質に乏しい小型 の細胞が䯣様充実性，胞巣性に増殖し，核分裂像も認 めた (図 5)。腺癌, 粘液癌, 扁平上皮湟などの混在は 認めなかった，深達度は粘膜下層の深層に達し筋層を 圧排するが，筋層以深への明らかな浸潤はみられな かった，背景胃粘膜には萎樎化生性の慢性胃炎の像が みられた。グリメリウス染色㓌性、Fontana-Masson 染色陰性で, 免疫組織化学的には epitherial membrane antigen (EMA) 晹性， ChromograninA 弱陽性, neuron specific enolase（NSE）弱陽性であった。胃癌

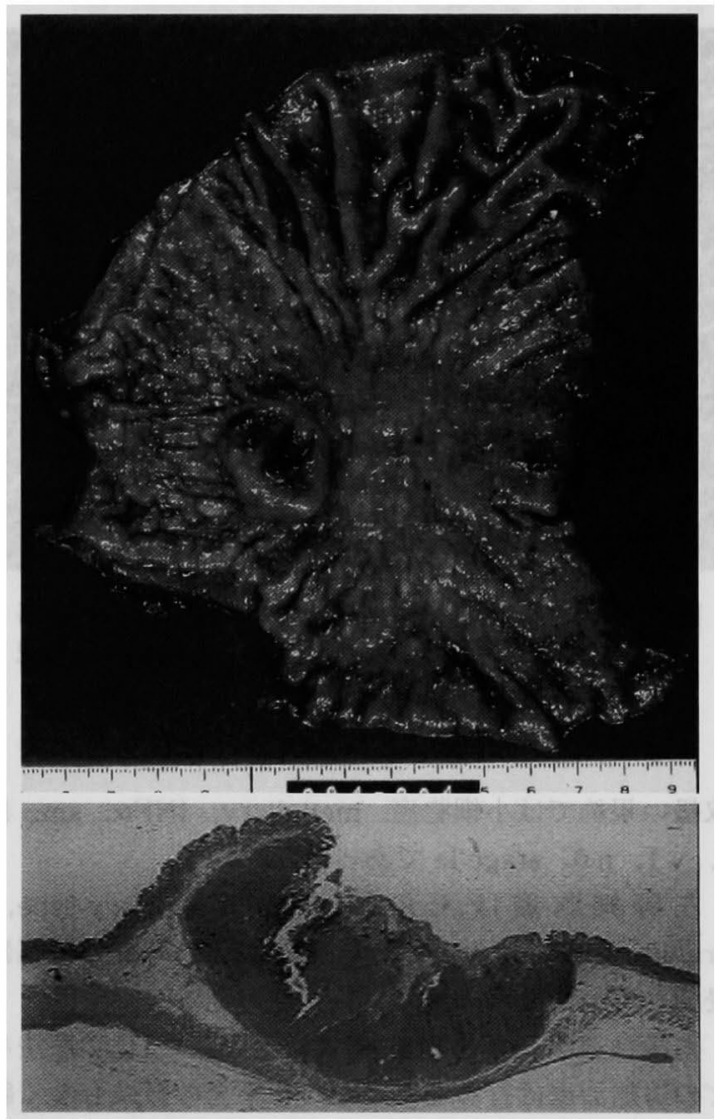

図 3 摘出標本とルーぺ像（胃）：幽門輪から $3 \mathrm{~cm}$ の 小紋に2 型様腫瘍を認めた (上段). 腫演は膨張性発 育を呈し筋首を圧排するが，筋層への浸潤はなかっ た（下段）。 


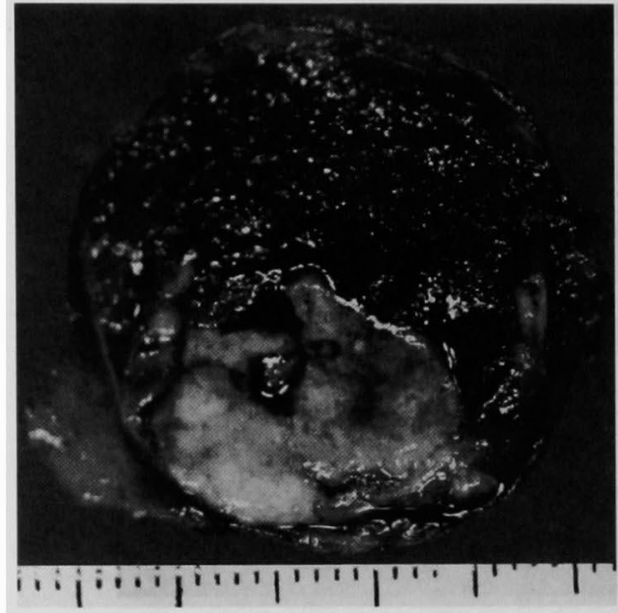

図 4 摘出標本 (左腎細胞癌, 割面)：左堅上極に大き さ $2.5 \mathrm{~cm}$ の腫瑒を認めた。

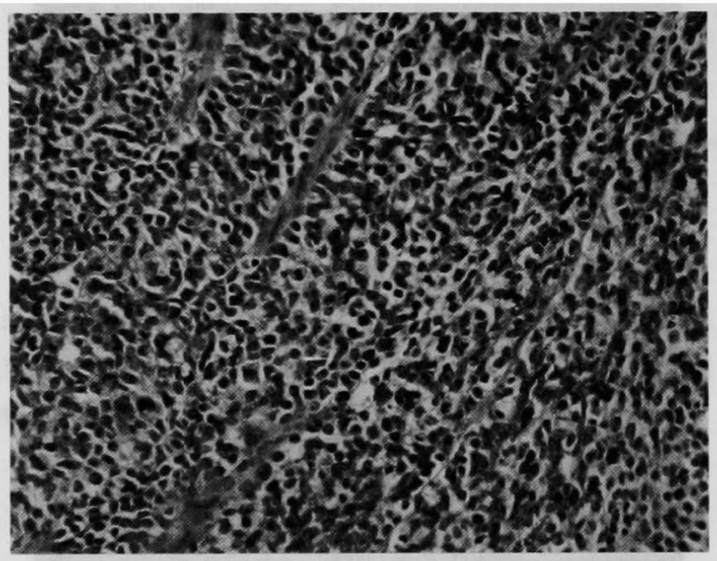

図 5 病理組權所見 (胃)：絊胞質に乏しい小型の腫瘍 細胞が㖪様充実性，胞柴性に增殖し，核分裂像も認 めた（HE 染色， × 200）。

取扱い規約では小細胞癌, medullary, INF $\alpha, s m, l y$ 1, v 1, n 0, stage Ia であった.

左腎細胞癌は大きさ $2.5 \mathrm{~cm}$ で papillary type, granular cell subtype であり（図 6 上)，一部で被膜に 浸潤していた。

術後経過は良好で第 37 病日に退院した. 化学療法な どの追加治療は行わなかった．腎不全の徴候もなく経 過観察していたが, 手術から 3 年 4 カ月後の 1997 年 5 月に左肺 $\mathrm{S}^{1+2}$ に異常陰影を認めた，胸腔鏡下に肺部分 切除を施行したところ，腎細胞癌の肺転移であった(図 6 下). 術後はインターフェロン治療を行い, 退院した.
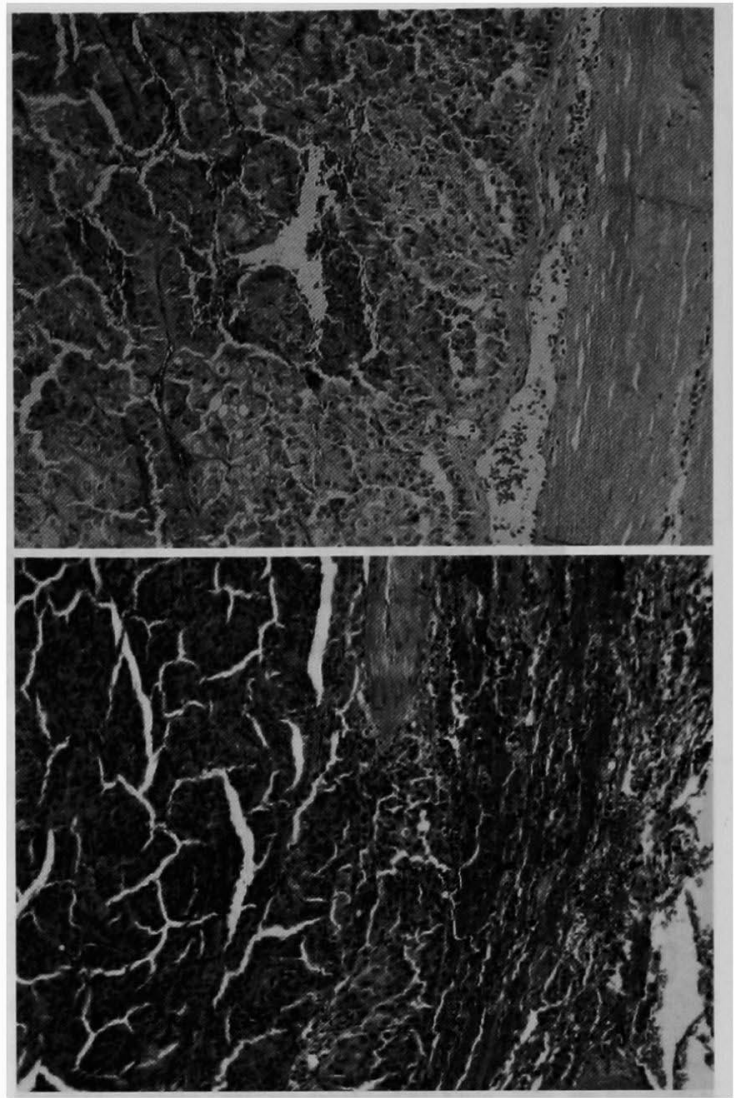

図 6 病理組所見（左腎細胞癌）: Papillary type, granular cell type であり，一部に被膜浸潤を認めた (上段, $\mathrm{HE}$ 杂色, $\times 200) .3$ 年 4 力月後の肺腫瑒の病 理組織所見は左腎細胞癌の組織像と同様であり，腎 細胞癌肺転移と診断した(下段，HE 染色， ×200).

初回手術から 5 年以上経過し, 腎細胞癌再発にたいし てインターフェロン治療中であるが, 胃小細胞癌の再 発徴候はなく外来通院中である.

$$
\text { 考察 }
$$

小細胞癌は肺癌の組織型としてみられることが多 く,肺以外の㖶器にも認められる". 肺以外の䑏器では 膀胱，前立腺，咽頭などに比較的多く，胃原発の小細 胞癌は稀である に報告し, 1991 年 Matsui ら"が 2 施設での 17 例を報 告, 1996 年井上ら ${ }^{5)} 25$ 例が文献的に集計している.

胃小細胞癌の診断は，肉眼的には 2 型や粘膜下腫瘍 の周堤を有するとされる．自験例も中心陥凹を有する 粘膜下腫瘍様の肉眼型を呈した。

組織学的には細胞質にそしく，大きさが均一な小型 
ないし中型の腫場細胞がシート状，充実性，索状に増 殖し，核はクロマチンに富み，核小体は目立たないが 核分裂像が多いとされる和。また組織化学染色や免疫 組織化学染色が有用とされ，自験例もダリメリウス染 色は陰性であったが, EMA 陽性, ChromograninA 弱陽性, NSE 弱陽性を螎示し, 光影的所見と併せて縄 䊉型の胃小紏胞㾔と診断した。

胃小細胞癌は転移浸潤僋向が強く臨床的にきわめて 悪性で, 治療は外科手術や化学療法が行われるが予後 きわめて不良である. 早期小細胞癌はこれまでに 2 例 が報告されているが，いずれもリンパ節転移が認めら れ，6力月”，1年 4 カ月"で死亡している。自験例は早 期癌として 3 例目であり，粘膜下層深層までの浸閏と 脈管侵蚝を認めたが、リンハ節転移は認めなかった。 術後化学療法を行わなかった自験例に長期生存が得ら れたのは，いわゆる微小転移が生じる前に外科切除が 可能であったためと考えられた.

胃癌と同時性あるいは異時性に重複する他臟器癌に は大搌㿋，子宮癌，肺癌などが多いが，腎細胞㿋との 重複は比較的稀である．胃㿋からみた腎細胞癌の重複 頻度は 2 4\%で, 胃癌と腎細胞癌の同時性重複癌で一 期的手術の行われた症例は 17 例が報告されている゙!. われわれの施設における1986 年から1996 年までの胃 癌手術症例は 963 例, 腎細胞癌症例は 65 例であり, 両 者の重複癌は 4 例 $(0.4 \%)$ であった. 4 例のうち胃癌. 腎細胞癌ともに一期的に根治術を施行しえたのは 2 例 であった，自験例の左腎細胞癌に対する術式は，被膜 浸閏のない小腎細胞癌であること，右腎低形成で右腎 機能を認めなかったことから腎部分切除術を施行し た. 術後 3 年 4 カ月目に肺転移をきたしたが，再切除 とインターフェロン治潦により，生活の質を落とすこ
となく 5 年以上生存中であり, 腎部分切除術が有用で あったと考えられた。

\section{結 語}

5 年生存中の胃原発小細胞癌と左腎細胞癌の同時性 重複触の1例を報告した。初回手術から 3 年 4 力月後 に，腎細胞癌の肺転移をきたし胸腔鏡下手術とイン ターフェロン治療を施行した。予後不良である胃原発 小細胞瘦で長期生存し，かつ腎細胞癌が重複しきわめ て稀な1例と考えられ報告した。

\section{文献}

1) Ibrahim NBN, Briggs JC, Corbishley $\mathrm{CM}$ : Extrapulmonary oat cell carcinoma. Cancer 54 : 1645-1661. 1984

2) Lo Re G. Canzonieri V. Veronesi A, et al : Extrapulmonary small cell carcinoma. Ann Oncol $5: 909-913,1994$

3) Matsusaka $T$, Watanabe $H$, Enjoji $M$ : Oat cell carcinoma of the stomach. 福同医誌 $67: 65-73$, 1976

4) Matsui K. Kitagawa M. Miwa A, et al : Small cell carcinoma of the stomach: A clinicopathologic study of 17 cases. Am J Gastroenterol $86: 1167-$ 1175, 1991

5）井上文彦，西田 修，水木 孝他：胃小細胞癌の 1 例. 胃と腸 31: 797-801, 1996

6）胃癌研究会編：胃癌取扱い規的．改訂第 12 版，金 原出版, 東京, 1993

7) Fukuda T. Ohnishi $Y$, Nishimaki T. et al : Early gastric cancer of the small cell type. Am J Gastroesterol 83 : 1176-1179, 1988

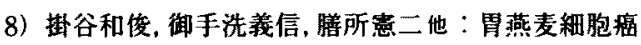
の2 例. 日臨外医会誌 $48: 1687-1692.1987$

9）三村卓司，金田道広。作本修一地：一期的根治手術

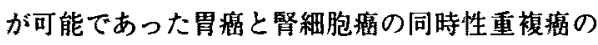
1 例. 虚の臨 $40: 423-428,1994$ 


\title{
A SYNCHRONOUS DOUBLE CANCER OF THE PRIMARY GASTRIC \\ SMALL-CELL CARCINOMA AND RENAL CELL CARCINOMA
}

\author{
Mitsuaki SAKATOKU, Mitsuyo KOSUGI, Hisayuki NAKASHIMA. \\ Kenichi IETSUGU, Kaoru KIYOHARA and Shintaro TERAHATA* \\ Departments of Surgery and Pathology*, Tonami General Hospital
}

\begin{abstract}
A 66-year-old man visited our hospital because of vertigo and vomitting. Endoscopically, an elevated lesion with delle was revealed at the antrum of the stomach. Abdominal CT and MRI revealed a right renal hypoplasia and left renal tumor, subsequently, distal gastrectomy and partial resection for the left renal tumor was performed. The final histological diagnosis was small-cell carcinoma of the stomach with findings of INF $\alpha$. medullary, sm, lyl, vl, n0, stage Ia and renal cell carcinoma papillary type, granular cell subtype. Forty months after operation, a left pulmonary nodule was detected and resected under thoracoscopic surgery. Histologically, the nodule was diagnosed as metastatic renal cell carcinoma and treated with interferon. Patients with gastric small-cell carcinoma are reported to have very poor prognosis, however, this patient in alive 5 years after the first operation, and is without renal failure.
\end{abstract}

